DOI: $10.37863 /$ umzh.v72i8.6213

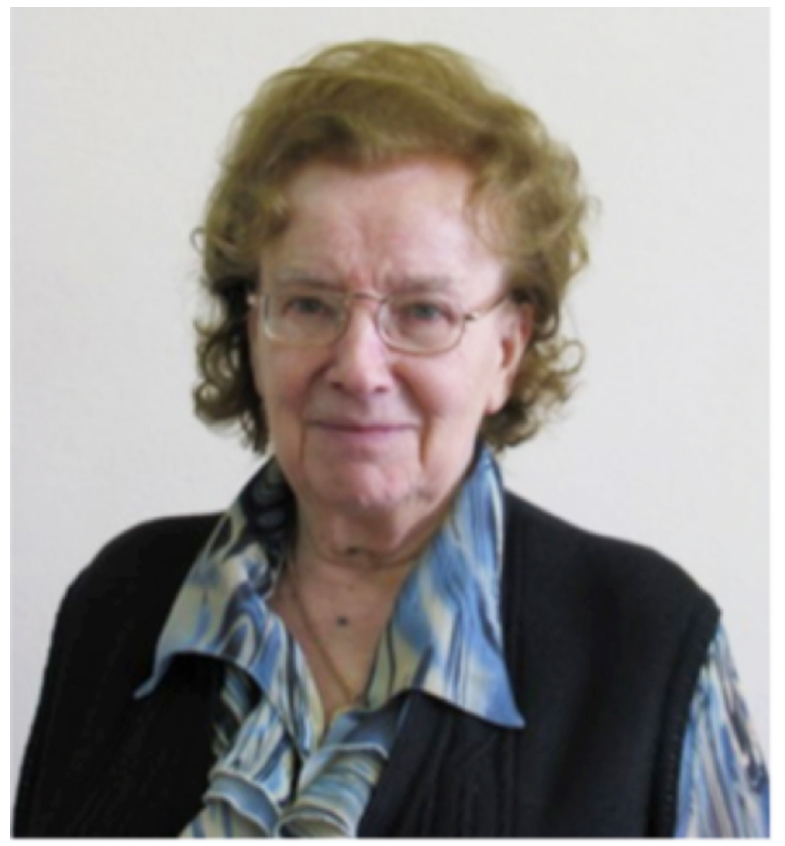

\title{
НІНА ОПАНАСІВНА ВІРЧЕНКО (до 90-річчя від дня народження)
}

П'ятого травня 2020 року виповнилося 90 років одній із відомих українських жінок-математиків, професору кафедри математичного аналізу та теорії ймовірностей фізико-математичного факультету КПІ імені Ігоря Сікорського, академіку АН Вищої школи України, дійсному члену Наукового товариства ім. Т. Шевченка, члену Українського, Американського, Австралійського, Бельгійського, Единбурзького, Лондонського математичних товариств, голові Науковометодичної ради Всеукраїнського товариства політв'язнів та репресованих, заслуженому діячу науки і техніки України Ніні Опанасівні Вірченко.

Народилася Н. О. Вірченко у селі Завадівка Корсунь-Шевченківського району Черкаської області. Батько Ніни, Опанас Іванович, був агрономом, мати, Олена Митрофанівна, - фельдшером-акушеркою.

Опанас Вірченко, як колишній старшина Української Народної Республіки, був засуджений радянською владою, перебував у в'язниці, з якої його товариші дивом допомогли йому втекти. Тому родина Вірченків була змушена часто змінювати своє місце проживання. Дев'ятий клас Ніна Вірченко закінчила в місті Червоному на Житомирщині, а випускний десятий клас із золотою медаллю - в місті Житомир, в середній школі № 36. 
Любов до математики, а згодом і до фізики, у Ніни Вірченко виникла дуже рано, ще в початковій школі. Дівчині пощастило з вчителями, а вчитися надихали батьки. В десятому класі вона вже твердо вирішила, що своє життя присвятить математиці. Восени 1946 року шістнадцятирічна Ніна стала студенткою механіко-математичного факультету Київського університету. Юна студентка з захопленням та великою цікавістю слухала блискучі лекції з аналітичної геометрії професора Б. Я. Букреєва, з математичного аналізу - доцента С. Г. Крейна.

„Із тих перших студентських літ, - згадує Н. О. Вірченко, - найбільше пам'ятаю радість неймовірну, неймовірну насолоду від занять математикою і нестерпне почуття голоду! Це ж був голодний в Україні 1947 рік. На лекціях формули змішувалися перед очима зі шматочками хліба...". Жила Ніна Вірченко в напівпідвальній кімнаті гуртожитку, де мешкало 19 студенток. Та не зважаючи на тяжкі умови, дівчина встигала відвідувати концерти, бібліотеки, студентський гурток з радіотехніки та аеродинаміки (була там єдиною дівчиною 3-поміж 29 хлопців), де вивчали будову літаків, розробляли проєкти вдосконалення польотів, здійснила 10 стрибків із парашутом.

Розмови допитливої студентки з товаришками по кімнаті щодо історії України, про ОУНУПА, про потребу української державності стали відомими НКВС через доноси впродовж півтора року найближчої подруги. Наслідком став арешт у червні 1948 року та звинувачення у „політичній змові, заколоті, який таємно готувався”, одиночна камера у в'язниці на вулиці Володимирській, 33 і швидкий вирок 8 січня 1949 року: десять років спецтаборів за „зраду Батьківщини й участь в українсько-націоналістичній банді”. Далі тяжка дорога у спецтабори „Озерлагу” (Тайшет, Іркутська область, Східний Сибір), де морози сягали сорока градусів, робота на лісоповалах, у кам'яному кар'єрі, хвороба на туберкульоз, послаблення зору, біль від втрати друзів. Шість років незмінна чорна роба з номером Р-840 ...

Ще студенткою Ніна придумала собі патріотичне ім'я УЖМА (Україна - Жінка - Математика - Астрономія), і іiі життя було відповідним. В неймовірно тяжких умовах дівчатаполітв'язні у таборах знаходили можливість і співати, і вишивати, і писати вірші, а Ніна ще й займалась математикою з бажаючими. Трималися гідно, а потім підтримували одна одну протягом усього життя. Після смерті Сталіна 30 січня 1954 року Ніну Вірченко було звільнено як таку, що була засуджена малолітньою. Вона повернулась у рідну Україну і до здобуття незалежності нашою країною перебувала під пильним наглядом КДБ (обшуки, підслуховування, допити, цілодобовий нагляд). Реабілітована Ніна Опанасівна Вірченко була лише в 1991 році.

Деякий час після звільнення з таборів Ніна Опанасівна викладала математику, фізику, малювання в школах Житомирської області. На стаціонар в університеті не дозволили поновитися, вдалося продовжити навчання на заочному відділенні механіко-математичного факультету Київського університету. Але математичні здібності та здобутки студентки були настільки вагомими, що згодом ії перевели на стаціонар.

Університет Н. О. Вірченко закінчила у 1961 році з червоним дипломом. КДБ СРСР не дав дозвіл на вступ до аспірантури, та вчені-патріоти академік I. Т. Швець, професори Г. М. Положій, І. І. Ляшко, доцент Н. О. Пахарєва взяли iї „на поруки”, і Ніна Вірченко стала аспіранткою кафедри математичної фізики КДУ імені Т. Г. Шевченка. В 1964 році вона успішно захистила кандидатську дисертацію, стала асистентом, потім старшим викладачем і 1967 року доцентом кафедри математичної фізики. 
Після „хрущовської відлиги” під час політичних „чисток” у 1973 році Ніну Опанасівну звільнили з університету. Восени того ж року вона стала доцентом кафедри вищої математики Київського політехнічного інституту, де працює й понині.

Захист докторської дисертації, яку Н. О. Вірченко присвятила своїм батькам і яку давно було підготовлено, через політичний тиск на неї відбувся лише в 1988 році, а у 1989 році Ніна Опанасівна отримала звання професора.

Професор Н. О. Вірченко - блискучий ерудований лектор, вона розробила й викладає ряд курсів з багатьох розділів математики на факультеті інформатики та обчислювальної техніки і на фізико-математичному факультеті: математичний аналіз, аналітичну геометрію, математичну фізику, спеціальні функції, історію та методику викладання математики. Тисячі студентів, яких навчала і навчає професор Н. О. Вірченко, яким дала путівку в життя, озброївши їх знаннями, чітким математичним мисленням, любов'ю до свого предмету та оптимістичним патріотичним ставленням до України, завдячують їй отриманим професіоналізмом, наснагою до творчості та наукової діяльності.

Під керівництвом професора Вірченко Н. О. захищено 10 кандидатських дисертацій. Від 1963 року Ніна Опанасівна незмінно керує роботою наукових семінарів „Крайові задачі. Спеціальні функції”, „Диференціальні рівняння та їх застосування”, методичним семінаром кафедри математичного аналізу та теорії ймовірностей.

Коло наукових інтересів професора Вірченко - теорія узагальнених аналітичних функцій, теорія мішаних крайових задач, сингулярні диференціальні рівняння з частинними похідними, інтегральні рівняння, спеціальні функції, інтегральні перетворення, історія та методика математики тощо.

Н. О. Вірченко є автором понад 500 наукових, науково-методичних та науково-популярних праць, серед них „Смешанные краевые задачи математической физики” (1985 р.), „Парні (потрійні) інтегральні рівняння” (1989р.), „Математика в афоризмах, цитатах, висловлюваннях” (видання українською 1974 р., російською 1984 р. та японською 1989 і 1995 рр. мовами), „Дробові інтегральні перетворення гіпергеометричного типу” (1995р.), „Графіки елементарних та спеціальних функцій” (1996р.), „Основні методи розв’язання задач математичної фізики” (1997р.), „Узагальнені функції Лежандра та їх застосування” (1998р.), “Generalized associated Legendre functions and their applications" (2001 p.), "Graphs of elementary and special functions" (2001р.), „Вибрані питання методики вищої математики” (2003р.), „Нариси з методики викладання вищої математики” (2006р.), „Основи дробового інтегро-диференціювання” (2007р.), „Класичні та узагальнені багатопараметричні функції” (2008р.), „Парні (N-арні) інтегральні рівняння” (2009р.), „Узагальнені інтегральні перетворення” (2013 р.), „Математичні усмішки” (2014р.), „Узагальнені гіпергеометричні функції” (2016р.). У 2019 році вийшла збірка поезій „Поетичні акорди”.

Слід відзначити величезний організаторський талант Ніни Опанасівни. Світова громадськість знає професора Вірченко Н. О. як активного дослідника життя і наукової творчості видатного українського математика 20-го століття М. П. Кравчука, безневинно знищеного на Колимі тоталітарним режимом. Ніна Опанасівна зробила неймовірно багато для того, щоб ім'я цього видатного вченого залишилось у пам'яті прийдешніх поколінь: провела вісімнадцять міжнародних наукових конференцій імені академіка Михайла Кравчука, в яких брали участь 
відомі вчені з багатьох країн світу, доклала чимало зусиль для відкриття аудиторії імені академіка Михайла Кравчука в КПІ імені Ігоря Сікорського (2002р.), відкриття пам'ятника вченому (2003 р.), створення фільму „Голгофа академіка Кравчука” (2004 р., режисер О. Рябокрис), найменування вулиці у Києві на честь його імені (2009р.), створення та підтримки музею Михайла Кравчука на його батьківщині, упорядкування та видання його творів „Науково-популярні праці” (2000р.), „Вибрані математичні праці” (2002р.), „Розвиток математичних ідей Михайла Кравчука" (2004р.).

Особливу цінність для молоді та історії становлять нариси Н. О. Вірченко про колишніх політв'язнів та репресованих, ії дослідження стосовно українських вчених. Не можна не згадати праці правозахисного характеру - „Про заборону української мови (XVII - XX ст.)”, „Дещо про українську математичну термінологію” та книгу споминів „Зернини з доріг життя мого...” (2011 p.).

Сумлінна та віддана праця Н. О. Вірченко, іiі багаторічна та багатогранна наукова, педагогічна та громадська діяльність відзначені низкою високих звань та нагород. Зокрема, вона є Соросівським професором (1997р.), лауреатом 1-ї премії НТУ України „КПІ” (1998р.), заслуженим викладачем (1999р.) та почесним професором (2006 р.) НТУ України „КПІ”, заслуженим працівником освіти України (2006р.), переможцем конкурсу „Викладач-дослідник2008”. Н. О. Вірченко має відзнаку МОН України „Петро Могила”, диплом (Cambridge) „Leading Scientist of the world-2010”, нагороду Святого Володимира АН Вищої школи України (2010р.).

Серце цієї непересічної людини сповнене безмежною любов'ю до свого покликання - до математики. Душу наповнює щирість, енергійність, працьовитість, душевна доброта, поєднана 3 безкомпромісністю до несправедливості.

Здійснено безліч планів, мрій, багато досягнень, велика кількість звершень, але й багато ще заплановано. Ніна Опанасівна - наша гордість, національний скарб, берегиня української духовності, вона запалює нас своєю енергією, завзятістю, наполегливістю, кришталевою чистотою, високою духовністю. Життя славетної українки Ніни Опанасівни Вірченко є взірцем для наслідування.

Тож бажаємо Ніні Опанасівні міцного здоров'я, щастя, здійснення мрій, нових звершень на благо України та українського народу, на славу і процвітання нашої Батьківщини.

А. М. Самойленко, О. І. Клесов, П. В. Задерей, Г. Д. Нефьодова, Н. М. Задерей, В. О. Гайдей 